\title{
Contemplating privatisation of China's rural land ownership
}

\author{
by Xiaoyang Zhang
}

$\Delta$ s far as China's land system as a whole is concerned, two basic principles should be borne in mind: (i) land in China is in public ownership (land itself is not permitted to be privately owned); and (ii) land use rights can be in private ownership, and under normal circumstances are permitted to be obtained and transacted. Urban land is owned by the state (Constitutional Law, art 10, para 1; Property Rights Law, art 47; Land Administration Law, art 8, para 1). Rural land and the land in suburbia are owned by rural collective organisations, unless otherwise provided by the law that it is owned by the state (Constitutional Law, art 10, para 2; Property Rights Law, art 47; Land Administration Law, art 8, para 2). The relevant provisions contained in the Constitutional Law 1982, the Land Administration Law 1986 and the Property Rights Law 2007 are, in most circumstances, of closest relevance to the issues pertaining to China's land system.

The privately-held rural land was ceded by peasants to rural collective organisations as the result of the collectivisation campaign accomplished in the 1950s that ultimately gave rise to the dismantling of private ownership of China's rural land. The market-oriented economic reform, a masterstroke from China's paramount leader Deng Xiaoping, was launched in the late 1970s. The eradication of bottlenecks that hindered the reform was spearheaded by carrying out the rural reform first; it was depicted as a "household responsibility system" to replace the regime of the people's communes.

Since China's rural land is owned collectively by rural communities other than that held privately by individual peasants, the household responsibility system needs to operate on the basis of a farmland contracting system, under which peasants enter into contracts with rural collective organisations to acquire a legitimate right to use land for engaging in agricultural activities. Within the contract period, the land use right can be transferred, swapped or sub-let; but the land in question normally cannot be used for non-agricultural purposes (Property Rights Law, art 128). Under the Land Administration Law, the contract period is capped at a maximum of 30 years (art 14, para 1).

However, under the Property Rights Law which was promulgated far more recently, when the current contract period ends, the peasant in question will be entitled to continue contracting the land presently in his possession (art 126, para 2). Moreover, each rural family is entitled to be allocated a piece of land to build a house and live in it; if the land given is destroyed due to a destructive force of nature, the family affected will be allocated the land afresh; but if the house is sold or rented out by the land user, the land user will not be eligible to be granted another piece (Land Administration Law, art 62, para 1 and 4; Property Rights Law, arts 152 and 154). The law prescribes no limitation on the length of time within which a rural family may use the land on which their dwelling house is located; from this can be surmised that their occupancy of the land could last for an unlimited period of time.

Since the tenure can patently be an unfixed and extremely lengthy one, the nature of China's rural land use right has sparked fierce debate over re-structuring the current system by reviving privatisation.

\section{ARGUMENTS IN FAVOUR OF PRIVATISATION}

Advocates of privatisation hold that to achieve urbanisation and modernisation in rural areas, land ownership must be privatised. The key reasons they put forward include the following three arguments.

First, privatisation would lead all rural land, including the land that stays idle and land allocated to peasants for establishing their dwellings, to become lawfully purchasable. Those peasants no longer deeming the land as a necessity for them may get rid of it for a gain. Chinese urban residents are currently prevented from purchasing houses built by individual peasants on their allocated home land, as the land is legally owned by the rural collective; if they covertly bought such houses, they would still not be able to hold legal title to the houses. Privatisation could address this problem.

Second, once privatisation allows rural houses to be sold on the open market, substantial price differences between rural and urban houses could contain or slow down the rise in house prices in major Chinese cities. This is against the backdrop that outrageous urban house prices are showing no apparent sign of imminent decline, albeit the government has taken various measures to try to clamp down on the soaring prices.

Third, privatisation would stimulate private investment in the agricultural sector. Once rural land is privatised and allowed to be sold, let, or treated as capital, this could 
eventually give rise to an increase in land value, an enhancement of production efficiency, and an enlargement of production scale.

\section{OPPOSING VIEWS}

Opponents to privatisation also put forward three arguments.

First, the success of urbanisation in history achieved by mature western economies was to a large extent attributable to the consequences of colonialisation and colonial expansion carried out by the countries involved. This is definitely not a model for China to imitate.

Second, in today's China only when peasants' freedom to leave home and find work in urban regions, as well as their freedom to return home and re-engage in agricultural work, could both be ensured would they be able to sustain a reasonable standard of living. If privatisation becomes reality, private rural land could easily fall prey to venture capitalists engaged in land expropriation, leading landless peasants to leave home and migrate to cities; such a situation could easily result in the massive emergence of impecunious communities in urban regions.

Finally, there is no strong evidence that a clear correlation exists between private land ownership and a corresponding surge of investment in agriculture. Most agricultural goods produced in China are supplied to domestic consumers other than for export. If land is privatised, an inflow of external capital (eg foreign capital) may have the effect of decreasing the portion of economic pie currently enjoyed by Chinese peasants.

\section{THE GOVERNMENT'S POSITION}

The Chinese government has once before unveiled its stance on the issue of privatisation in 2008, and under it the system of collective ownership of rural land would remain unchanged.

In 2011, Chinese Premier Wen Jiabao expounded on the importance of safeguarding Chinese peasants' legitimate rights against infringement. In his article on China's agricultural development, Wen emphasised the inviolability of any property right granted to peasants (particularly the right to use the land contracted from rural collectives, the right to use the land upon which peasants' dwellings are constructed, and the right to share the benefits derived from what rural collective organisations have earned from their activities). He pointed out that any such right shall not be deprived of under any circumstances, even in the event that it might no longer have a significant bearing on a peasant's life, and regardless of whether the peasant concerned still currently remains domiciled in his rural hometown.

\section{CONCLUDING REMARKS}

Although advocates of privatisation strive for what seems to be a forlorn hope, the debate over the pros and cons of privatising rural land ownership continues. At some point in the future, this may spur a new round of argument over the issues involved. When the view is put forward that one of the original purposes of the Chinese revolution was to realise an ideal of letting each and every peasant have a piece of land which he could eventually own, this casts doubt on whether a line has been drawn under the contentious issue of rural land ownership. Even though private ownership is legally unavailable at the moment, advocates of privatisation may set another goal, the attainment of which would at least lead to the right of usufruct over rural land in China coming close to de facto ownership.

\section{Xiaoyang Zhang}

Associate Professor (Business Law), Lee Shau Kee School of Business \&

Administration, The Open University of Hong Kong.

\section{REFERENCES}

Xuefeng He, 'Land must not be privatised' (Chinese), 2010, http://www.aisixiang.com/data/38046.html.

Immanuel C Y Hsu, The Rise of Modern China (Chinese), The Chinese University Press 2002.

Reeitsu Kojima, "Agricultural Organization: New Forms, New Contradictions" in Y Y Kueh and Robert Ash (eds), Economic Trends in Chinese Agriculture, Clarendon Press, 1993.

Shanguang Kong, "Securitisation and privatisation of rural land" (Chinese), 2005, http://www.chinavalue.net/ Finance/Article/2005-3-21/3565.html.

Zhe Kuai and Fuyou Cai, "Privatisation of China's rural land is the road that must be taken towards tackling three agriculture-related big issues and achieving modernization" (Chinese), 2007, http://www.zgxcfx.com/ Article/1951.html.

Yue Ma, "A reflection on rural land ownership" (Chinese), 2009 http://www.chinareform.org.cn/cirdbbs/dispbbs.asp? BoardID=11\&ID=215923.

Carl Riskin, China's Political Economy - the Quest for Development Since 1949, Oxford University Press, 1988.

Xing Su, The Economic History of New China (Chinese), Central Party School Press, 1999.

Jiabo Wen, "China's agriculture and the paths of rural development" (Chinese), 2012 http:/www.agri.gov.cn/ V20/ZX/nyyw/201201/t20120117 2458139.htm.

Tiejun Wen, "Why shouldn't China privatise rural land?" (Chinese), 2009, http://www.aisixiang.com/data/24349.html.

Elizabeth Wright, The Chinese People Stand Up, BBC Books, 1989.

Decai Yang, A New Study on Chinese Economic History (Chinese), Economic Science Press, 2009.

Meng Zhang, "Privatisation of land ownership is the road that must be taken towards meeting the objective of reform and open-up" (Chinese), 2009, http://www.zgxcfx.com/ Article/13306.html.

Wang Jianxun, "Land privatisation will definitely lead to a fall in urban house prices" (Chinese) http://business.sohu.com/20091219/n269066968.shtml. 